\title{
Automatic stabilization and discretionary fiscal policy in the financial crisis
}

\author{
Mathias Dolls ${ }^{1}$, Clemens Fuest ${ }^{2}$ and Andreas Peichl ${ }^{1 *}$
}

\footnotetext{
* Correspondence: peichl@iza.org

${ }^{1}$ IZA, Schaumburg-Lippe-Str. 5-9, 53113, Bonn, Germany

Full list of author information is

available at the end of the article
}

\begin{abstract}
This paper investigates the relationship between the magnitude of automatic stabilizers in the tax and transfer systems of 19 EU countries and the US, and discretionary fiscal stimulus packages passed by these countries during the recent economic crisis. In particular, we ask whether countries with larger automatic stabilizers have enacted smaller discretionary fiscal stimulus programs. Our results support this hypothesis. Our findings also suggest that social transfers, in particular the rather generous systems of unemployment insurance in Europe, play a key role for the stabilization of disposable incomes and explain a large part of the difference in automatic stabilizers between Europe and the US.
\end{abstract}

Keywords: Automatic stabilizer, Economic crisis, Taxes and benefits, Fiscal policy JEL Codes: E32, E63, H2, H31

\section{Introduction}

In the debate on policy responses to the recent crisis, some countries have been criticized for being reluctant to enact fiscal stimulus programs in order to stabilize demand, in particular Germany. One reaction to this criticism was to point to the fact that automatic stabilizers in Germany are more important than in other countries, so that less discretionary action is required. This raises the general question of whether countries with weaker automatic stabilizers have taken more discretionary fiscal policy action to compensate for this.

The recent recession triggered by the financial crisis has had a severe impact on incomes and employment around the world and especially in Europe (OECD 2012). While it is uncontroversial that both the magnitude of the economic contraction during the crisis and its effects on labor markets were attenuated considerably by the work of automatic and discretionary stabilization, a large part of the resulting policy debate has focused on the size of discretionary fiscal policy plans and on rescue packages for banks. Much less attention has been devoted to the workings of automatic stabilizers. Automatic stabilizers are usually defined as those elements of fiscal policy which reduce tax burdens and increase public spending without discretionary government action. In particular, automatic stabilizers provide income replacement immediately when unemployment starts to rise. During the recent crisis, the tax and benefit system has acted as an automatic stabilizer on both the revenue as well as the expenditure side of the general government budget. Due to differences related to the structure and financing of the tax benefit system, the degree of automatic stabilization was bound to vary across countries.

(c) 2012 Dolls et al.; licensee Springer. This is an Open Access article distributed under the terms of the Creative Commons Attribution License (http://creativecommons.org/licenses/by/2.0), which permits unrestricted use, distribution, and reproduction in any medium, provided the original work is properly cited. 
Automatic stabilizers are widely seen to play a key role in providing income insurance for households and hence in stabilizing demand and output. The automatic action of tax-transfer policies was accompanied in most countries by discretionary action in the field of tax, social and labor market policy. This action included a broad range of measures such as (payroll) tax cuts, employment incentives, activation policies, higher benefits and increased transfers to low-income households. Therefore, especially for the recent crisis, it is important to assess the contribution of automatic stabilizers to the overall fiscal expansion and to compare their magnitude across countries. Understanding the relationship between automatic stabilizers and discretionary fiscal policy is crucial, because countries with larger automatic stabilizers have to rely less on discretionary fiscal stimulus packages, other things being equal. As final data on fiscal stimulus packages during the recent economic crisis are now available, it is possible to shed light on this relationship. This is the purpose of this paper.

We build on former work (see Dolls et al. 2012) which investigates the magnitude of automatic stabilizers inherent in the tax and transfer systems of $19 \mathrm{EU}$ countries plus the US ${ }^{1}$. We relate these estimates of automatic stabilizers to new information on discretionary fiscal stimuli. Our empirical analysis points to a robust negative relationship between these two pillars of fiscal and social policy. This suggests that policy makers may indeed have taken into consideration the strength of automatic stabilizers when they decided how much to spend on discretionary fiscal policy packages in the crisis. These results are interesting because they shed new light on the factors determining the fiscal policy response of governments to the crisis. Our findings have important implications for the ongoing policy debate about institutional reforms following the sovereign debt crisis. While it is clear that balanced budgets need to be achieved in the medium-run, it is important to take into account the impact of reforms on automatic stabilizers. Also, our results support the argument that countries that have enacted smaller stimulus programs were countries with more automatic stabilizers. Of course, automatic stabilizers should not be the only determinant of discretionary programs. Other factors like the initial budgetary position or the size of the shock in the country under consideration have to be taken into account.

What is the contribution of this paper, relative to the existing literature? To the best of our knowledge, we are the first who analyze this relationship for the recent economic crisis with a direct measure for the magnitude of automatic stabilizers and upto-date data on fiscal stimulus packages. The (IMF 2009), using the average ratio of revenue to GDP as an indirect measure for automatic stabilization, finds a negative relationship between government size and the size of the discretionary fiscal impulse ${ }^{2}$. Moreover, as their work was done at an early stage in the recession, they rely on projections for discretionary measures (see IMF (2009)). However, in (Dolls et al. 2012), we show that simple macro measures such as the tax revenue to GDP ratio only partially predict the amount of automatic stabilization. In a similar vein, the (OECD 2009) finds an inverse relationship between the size of fiscal packages and automatic stabilizers, but also uses projections for fiscal stimulus and a measure for automatic stabilization which is conceptually not comparable to ours as it is based on the cyclical sensitivity of the budget to the economic cycle (see Girouard and André 2005).

Two recent contributions investigate the cross-country variation in fiscal stimulus during the crisis ((Bénétrix and Lane 2010) and (Aaizenman and Jinjarak 2010)) and 
relate it to several explanatory variables (e.g. pre-crisis GDP per capita, trade openness, fiscal space), but do not account for the amount of automatic stabilization. Interestingly and in line with our hypothesis, (Auerbach 2009) points to the fact that automatic stabilizers have been historically low in the pre-crisis years 2003-7 in the U.S. and concludes that this low level of automatic stabilization is one potential explanation for policy decisions with regard to discretionary fiscal policy during the recent economic crisis in the US.

The rest of the paper is organized as follows. In Section 2, we describe the conceptual framework and the empirical approach. Section 3 presents the results for automatic stabilizers and section 4 the relationship with discretionary fiscal policy. Section 5 concludes.

\section{Conceptual framework and empirical approach framework}

\subsection{Theoretical background}

Economic stabilization is primarily associated with the ability of taxes and transfers to stabilize income and in consequence consumption automatically in the face of economic downturns. The stabilizing character of the tax and transfer system relies on a simple mechanism: In the presence of a negative shock to income, taxes net of transfers decline, so that the negative shock on disposable income is smaller than it would be in the absence of the tax and transfer system. Several components of government budgets are affected by the macroeconomic situation in ways that operate to smooth the business cycle, with progressive income taxes and out-of-work benefits being the most prominent example. Automatic stabilization might have effects not only on disposable income but also on GDP itself. If in a recession, fewer taxes are collected and more transfers are paid. This should support private incomes and damp adverse movements in aggregate demand. We can expect this stabilizing property to be stronger if the tax system is more progressive (van den Noord 2000).

The extent to which automatic stabilizers mitigate the impact of income shocks on household demand essentially depends on two factors. Firstly, the tax and transfer system determines the way in which a given shock to gross income translates into a change in disposable income. For instance, in the presence of a proportional income tax with a tax rate of $40 \%$, a shock on gross income of one hundred Euros leads to a decline in disposable income of 60 Euros. In this case, the tax absorbs $40 \%$ of the shock to gross income. A progressive tax, in turn, would have a stronger stabilizing effect. The second factor is the link between current disposable income and current demand for goods and services. If the income shock is perceived as transitory and current demand depends on some concept of permanent income, and if households can borrow or use accumulated savings, their demand will not change. In this case, the impact of automatic stabilizers on current demand would be equal to zero. Things are different, though, if households were liquidity constrained. In this case, their current expenditures do depend on disposable income so that automatic stabilizers play a role. However, in this paper, we will concentrate on the first factor, the stabilization of disposable income aftershocks on gross income (see Dolls et al. 2012 for the stabilization of household demand).

A common measure for estimating automatic stabilization is the "normalized tax change" used by (Auerbach and Feenberg 2000) which can be interpreted as "the tax system's built-in flexibility" (Pechman (1973; 1987)). Based on this idea, in (Dolls et al. 2012), 
we define the "income stabilization coefficient" $\mathrm{\tau}$ which shows how changes in market income (defined as the sum of all incomes from market activities such as (self)-employment, business and property income) $Y^{M}$ translate into changes in disposable income (market income minus taxes plus benefits) $Y^{D}$ through changes in net tax payments $G$. We extend the concept of normalized tax change to include (direct) taxes as well as transfers. We take into account personal income taxes (at all government levels), social insurance contributions as well as payroll taxes and transfers to private households such as out-of-work benefits $^{3}$. (Dolls et al. 2012) show that the income stabilization coefficient can be derived from any general functional relationship between disposable income and market income. The derivation can be either done on the macro or on the micro level. On the macro level, it holds that the aggregate change in market income is transmitted via $\tau$ into an aggregate change in disposable income. However, one problem for the computation with macro data is that this data includes behavioral and general equilibrium effects as well as active fiscal policy. Therefore, a measure of automatic stabilization based on macro data captures all these effects. In order to single out the pure size of automatic stabilization, we compute $\mathrm{\tau}$ using arithmetic changes $(\Delta)$ in total disposable income $\left(\sum_{i} \Delta Y_{i}^{D}\right)$ and market income $\left(\sum_{i} \Delta Y_{i}^{M}\right)$ based on household micro level information:

$$
\begin{aligned}
& \sum_{i} \Delta Y_{i}^{D}=(1-\tau) \sum_{i} \Delta Y_{i}^{M} \\
& \tau=1-\frac{\sum_{i} \Delta Y_{i}^{D}}{\sum_{i} \Delta Y_{i}^{M}}=\frac{\sum_{i}\left(\Delta Y_{i}^{M}-\Delta Y_{i}^{D}\right)}{\sum_{i} \Delta Y_{i}^{M}}
\end{aligned}
$$

Computations are done according to the tax benefit rules which were in force before 2008 in order to avoid an endogeneity problem resulting from policy responses after the start of the crisis.

\subsection{Microsimulation using TAXSIM and EUROMOD}

We use microsimulation techniques to simulate taxes, benefits and disposable income under different scenarios for a representative micro-data sample of households. Simulation analysis allows conducting a controlled experiment by changing the parameters of interest while holding everything else constant. In particular, we are able to investigate the causal effects of different types of shocks on household disposable income and to avoid endogeneity problems when identifying the counterfactual effects (see Bourguignon and Spadaro (2006)). We can hence single out the role of automatic stabilization which is not possible in an ex-post evaluation (or with macro data) as it is not possible to disentangle the effects of automatic stabilizers, active fiscal and monetary policy and behavioral responses like changes in labor supply or benefit take-up.

Simulations are carried out using TAXSIM - the NBER's model for calculating liabilities under US Federal and State income tax laws from individual data - and EUROMOD, a static tax-benefit model for 19 EU countries, which was designed for comparative analysis ${ }^{4}$. The models can simulate most direct taxes and benefits except those based on previous contributions as this information is usually not available from the cross-sectional survey data used as input datasets. Information on these instruments is taken directly from the original data sources. Both models assume full benefit take-up and tax compliance, focusing on the intended effects of tax-benefit systems. 
These assumptions create an upwards bias on the automatic stabilizer measure - especially in countries where means-tested benefits are important (e.g., Ireland, UK), as take-up rates are typically much lower than for insurance benefits. The main stages of the simulations are the following. First, a representative micro-data sample and the according, pre-crisis tax-benefit rules (as of January $1^{\text {st }}$, 2008) are read into the model. Then for each tax and benefit instrument, the model constructs corresponding assessment units, ascertains which are eligible for that instrument and determines the amount of benefit or tax liability for each member of the unit. Finally, after all taxes and benefits in question are simulated, disposable income is calculated.

\subsection{Scenarios}

The existing literature on stabilization so far has concentrated on increases in earnings or gross incomes to examine the stabilizing impact of tax benefit systems. In the light of the recent economic crisis, there is more interest in a downturn scenario. Reinhart and Rogoff (2009) stress that recessions following a financial crisis have particularly severe effects on asset prices, output and unemployment. Therefore, we run two controlled experiments of macro shocks to income and employment. The first is a proportional decline in household gross income by $5 \%$ (income shock). This is the usual way of modeling shocks in simulation studies analyzing automatic stabilizers. However, economic downturns typically affect households asymmetrically, with some households losing their jobs and suffering a sharp decline in income and other households being much less affected, as wages are usually rigid in the short term. We therefore consider a second, idiosyncratic macro shock where some households become unemployed and therefore lose all their labor earnings (unemployment shock). In this scenario, the unemployment rate increases such that total household income decreases by $5 \%$ as well in order to make both scenarios as comparable as possible 5 .

Dolls et al. (2012) show that the two types of shocks and the resulting stabilization coefficients can be interpreted along the lines of average effective marginal tax rates (EMTR) for the whole tax benefit system at the intensive (proportional income shock) or extensive (unemployment shock) margin (see, e.g., Immvervoll 2004). Our measures of automatic stabilization differ from conventional EMTRs as we take into account income and payroll taxes as well as social benefits. In addition, instead of averaging individual EMTRs, the measure of automatic stabilization looks at the total change in market and disposable incomes.

The increase of the unemployment rate is modeled through reweighting of our samples $^{6}$. The weights of the unemployed are increased while those of the employed with similar characteristics are decreased, i.e., in effect, a fraction of employed households is made unemployed. With this reweighting approach we control for several individual and household characteristics that determine the risk of becoming unemployed. The implicit assumption behind this approach is that the socio-demographic characteristics of the unemployed remain constant ${ }^{7}$.

\section{Automatic stabilization}

In this section, we report and discuss the most important results from (Dolls et al. 2012) which will be the input for the main analysis in the next section. 
We start our analysis by comparing the US to Europe. Our simulation model includes 19 European countries which we treat as one single country (i.e. the "United States of Europe"). All of them are EU Member States, which is why we refer to this group as the EU, bearing in mind that some EU member countries are missing. We also consider the countries of the Euro area and refer to this group as 'Euro'. Figure 1 summarizes the results of our baseline simulation, which focuses on the income tax, social insurance contributions (or payroll taxes) paid by employees and benefits. Consider first the income shock. Approximately 38\% of such a shock would be absorbed by automatic stabilizers in the EU (and Euroland). For the US, we find a slightly lower value of $32 \%$. This difference of just six percentage points is surprising in so far as automatic stabilizers in Europe are usually considered to be drastically higher than in the $\mathrm{US}^{8}$. Our results qualify this view to a certain degree; at least as far as proportional income shocks are concerned. Figure 1 shows that taxes and social insurance contributions are the dominating factors which drive $\tau$ in case of a uniform income shock. Benefits are of minor importance in this scenario.

In the case of the unemployment shock, the difference between the EU and the US is larger. EU automatic stabilizers now absorb $47 \%$ of the shock (49\% in the Euro zone) whereas the stabilization effect in the US is only $34 \%$. This difference can be explained with the importance of out-of-work benefits which account for a large part of stabilization in Europe in this scenario. Benefits alone absorb 19\% of the shock in Europe compared to just $7 \%$ in the US 9

\subsection{Cross-country differences}

The results for the stabilization coefficient vary considerably across countries, as can be seen from Figure 2. In the case of the income shock, we find the highest stabilization coefficient for Denmark, where automatic stabilizers cushion $56 \%$ of the shock. Belgium

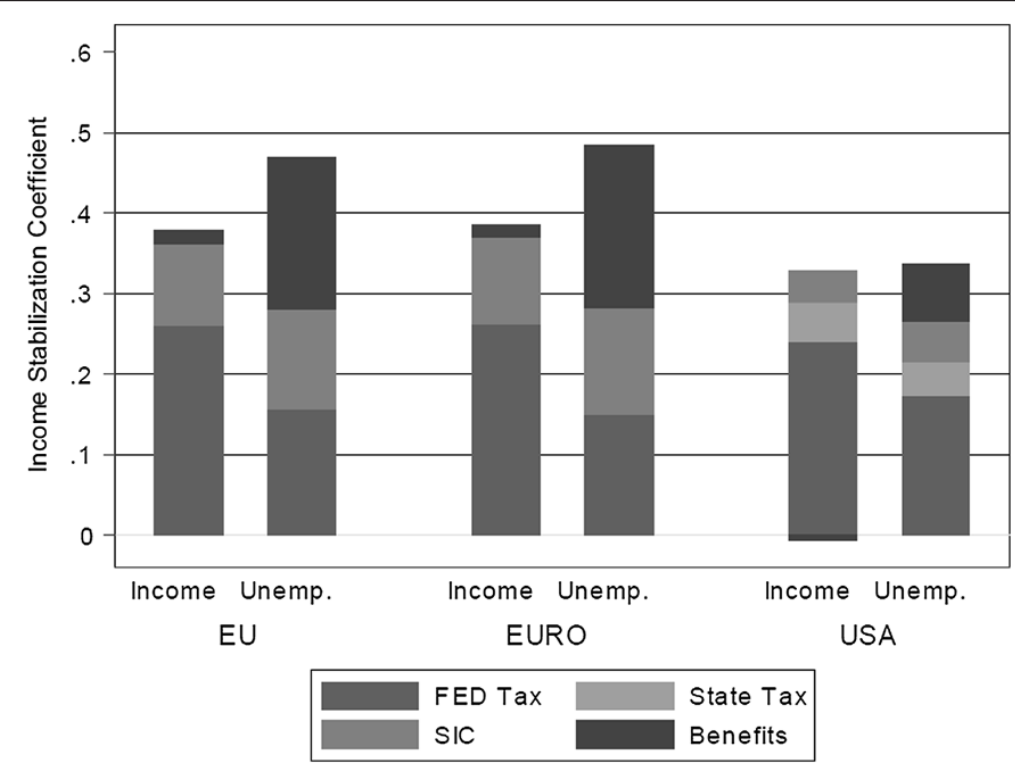

Figure 1 Decomposition of stabilization coefficient for both scenarios - US vs. EU. 


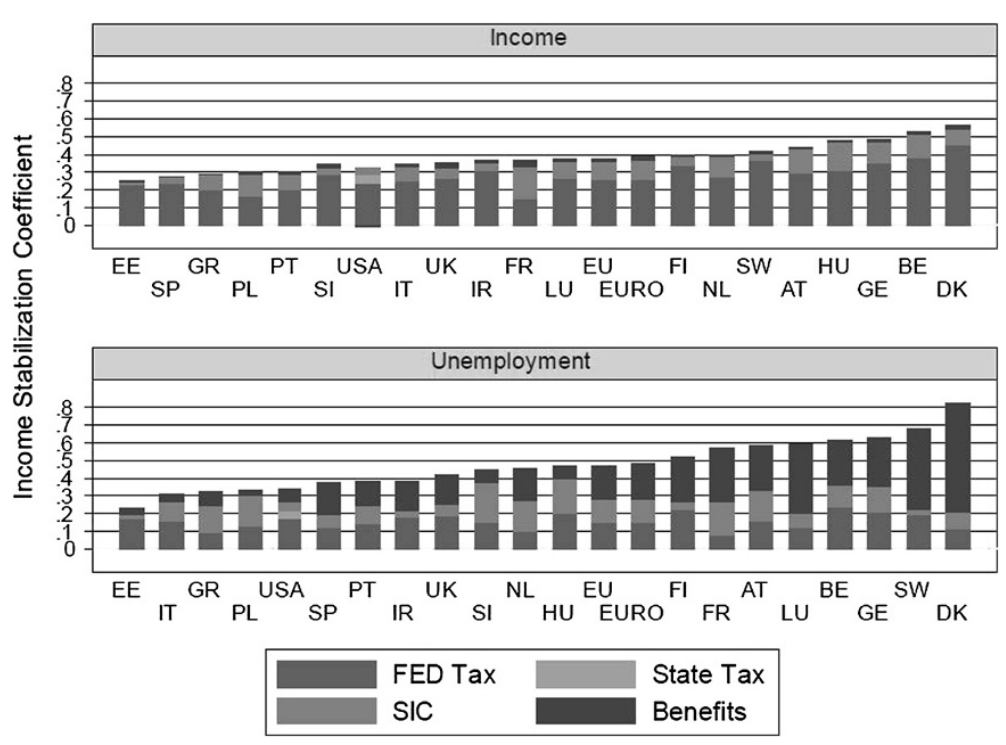

Figure 2 Decomposition of income stabilization coefficient for both scenarios -Country Ranking.

(53\%), Germany (48\%) and Hungary (48\%) also have strong automatic stabilizers. The lowest values are found for Estonia (25\%), Spain (28\%) and Greece (29\%). With the exception of France, taxes seem to have a stronger stabilizing role than social security contributions.

In case of the unemployment shock, the stabilization coefficients are larger for the majority of countries. Again, the highest value emerges for Denmark (82\%), followed by Sweden (68\%), Germany (62\%), Belgium (61\%) and Luxembourg (59\%). The relatively low value of stabilization from (unemployment) benefits in Finland compared to its neighboring Nordic countries might be surprising at a first glance but can be explained with the fact that Finland has the least generous unemployment benefits of the Nordic countries (see Aaberge et al. (2000)). Hungary (47\%) is now at the EU average due to the relatively low level of unemployment benefits. At the other end of the spectrum, there are some countries with values below the US level of 34\%. These include Estonia (23\%), Italy (31\%), and, to a lesser extent, Poland (33\%).

When looking only at the personal income tax, it is surprising that the values for the US (federal and state level income tax combined) are higher than the EU average. To some extent, this qualifies the widespread view that tax progressivity is higher in Europe (e.g., Alesina and Glaeser (2004) or Piketty and Saez (2007)). Of course, this can be partly explained by the considerable heterogeneity within Europe. But still, only a few countries like Belgium, Germany and the Nordic countries have higher contributions of stabilization coming from the personal income tax.

It is a striking feature of our results that automatic stabilizers differ significantly within Europe. In particular, automatic stabilizers in Eastern and Southern European countries are much weaker than in the rest of Europe. One factor contributing to this is that government size is often positively correlated with per capita incomes, at least in Europe. The stabilization of disposable incomes will therefore be higher in high income countries, just as a side effect of a larger public sector. 
In addition, it can be seen from Figure 3 that there is a clear positive relationship between our measure of automatic stabilization and effective average tax rates - which is not surprising given its definition.

The relationship between effective average tax rates and the stabilization coefficient for the unemployment shock is weaker as shown in Figure 4. The reason is that the latter depends to a large extent on the generosity of unemployment benefits.

\section{Automatic stabilizers and discretionary fiscal policy during the crisis}

During the crisis, policy-makers implemented a number of discretionary reforms to social protection systems. In most countries, social protection was increased with a number of measures targeted at families with children and households exposed to poverty risks. Other measures were aimed at maintaining or facilitating (re)employment. Another set of policies was geared at encouraging flexible working time, thus enhancing internal flexibility, and more in general at cutting labor costs.

We use up-to-date data on fiscal stimulus packages from the (IMF 2012) and the (OECD 2010) which slightly differ in terms of measurement of active fiscal policy. Conceptually, fiscal policy can be measured by changes in the actual budget balance which can be split up into a cyclical and a structural component. The total change in the budget balance reflects the effect of both automatic stabilizers and discretionary fiscal policy and does not allow us to compare the two pillars of fiscal policy see e.g. (Fatás and Mihov 2009).

In a first step, we consider the relationship between the cumulative change in the cyclical government balance 2009-11 in per cent of 2008 GDP and our measure for automatic stabilizers. Figures 5 and 6 reveal a significant negative relationship between the stabilization coefficient and changes in the cyclical balance. That is, the higher the built-in automatic stabilizers, the larger the cyclical deficit during the crisis. However,

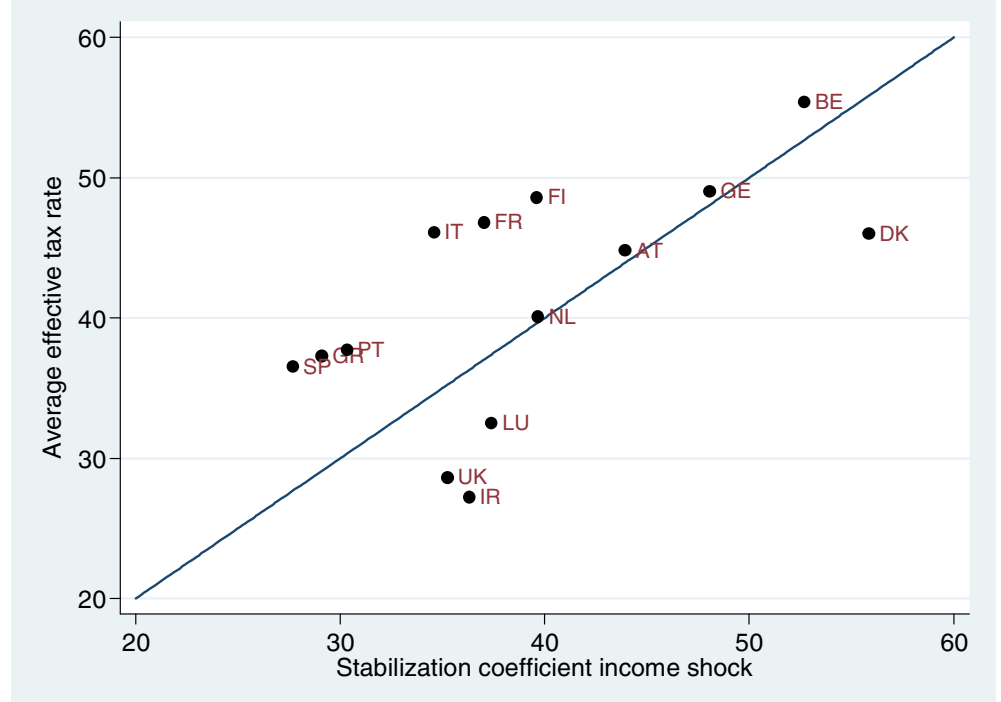

Figure 3 EATR and automatic stabilizers. Source: Own calculations based on (EUROMOD and TAXSIM and Immvervoll 2004). 


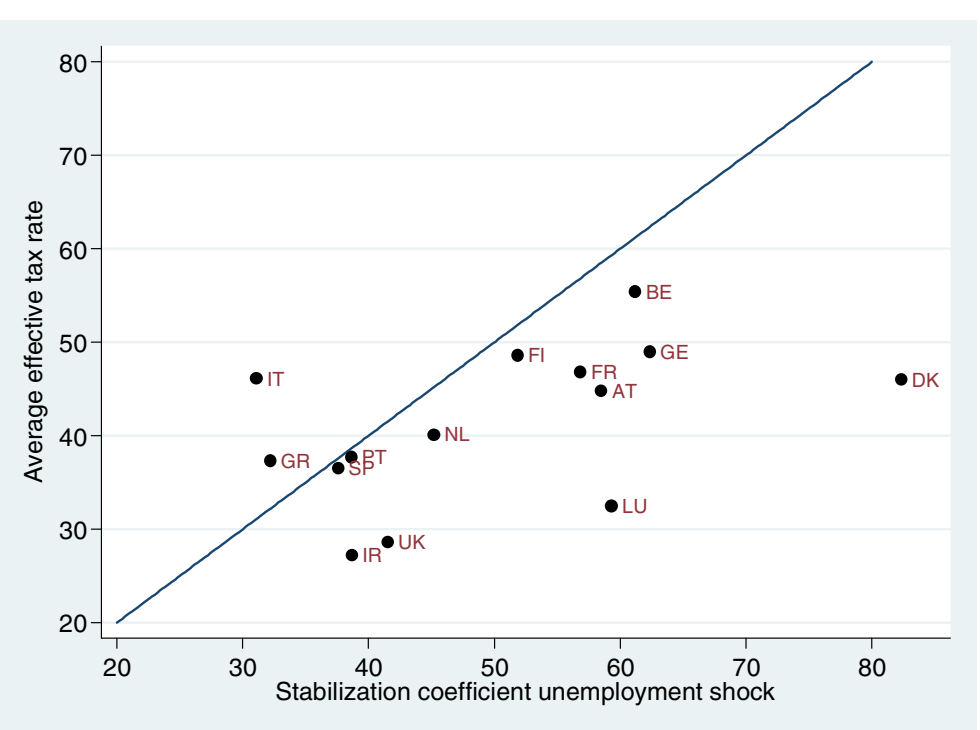

Figure 4 EATR and automatic stabilizers (unemployment shock). Source: Own calculations based on (EUROMOD and TAXSIM and Immervoll 2004).

as noted above, this measure for the cyclical balance does not capture discretionary fiscal policy.

Therefore, in the next step, we look at the structural balance in order to analyze the relationship between automatic and discretionary policies. We calculate the change in the structural balance between the pre-crisis year 2007 and the average for the years 2008-11 in order to focus on the endogenous response of fiscal policy to the economic crisis $^{10}$. Higher values of this measure of active fiscal policy indicate larger fiscal packages. We also distinguish discretionary fiscal policies in the years 2008-2009 and 2010-2011 given that

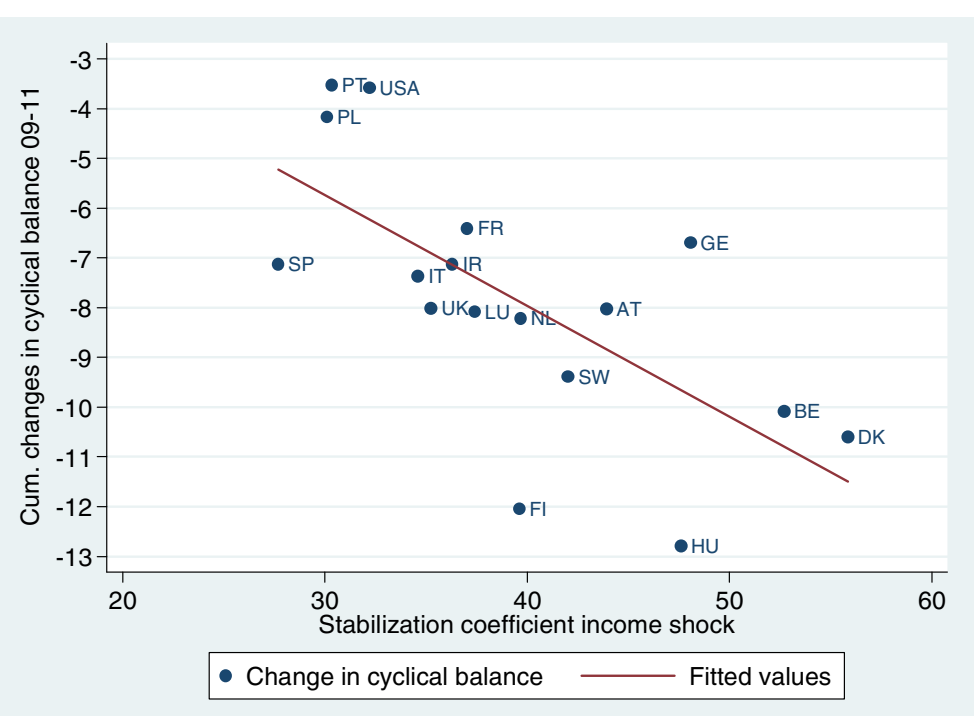

Figure $\mathbf{5}$ Change in cyclical balance and automatic stabilizers. Source: Own calculations based on (EUROMOD and TAXSIM and OECD 2010). 


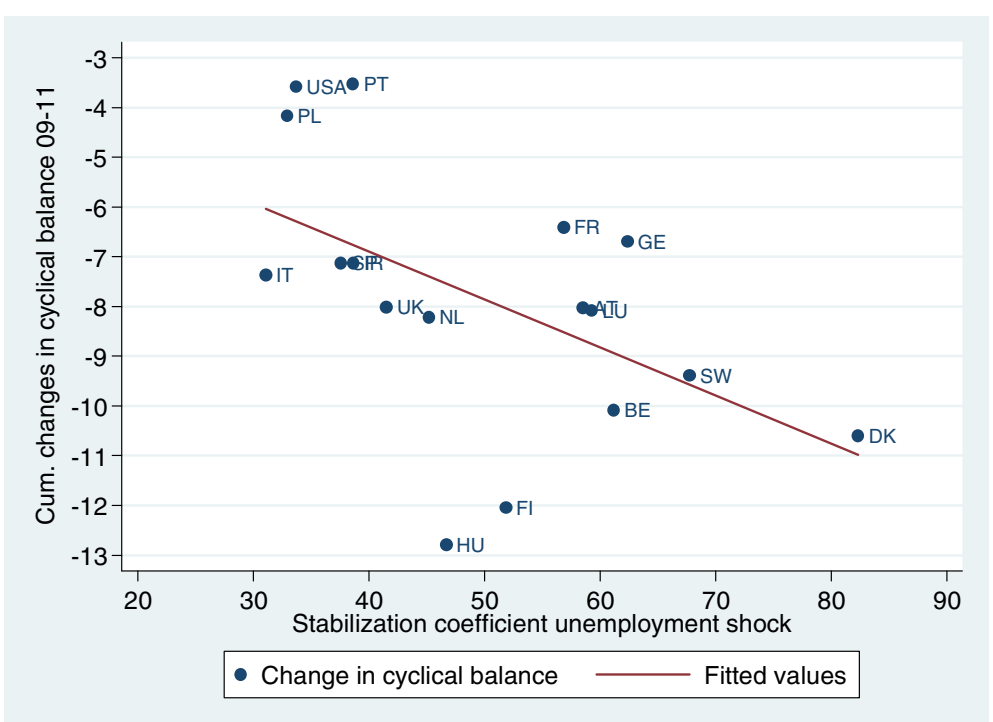

Figure 6 Change in cyclical balance and automatic stabilizers (unemployment shock). Source: Own calculations based on (EUROMOD and TAXSIM and OECD 2010).

fiscal policy changed substantially in some countries in the course of the crisis. In (OECD 2010) the size of the fiscal packages is determined as the deviation of fiscal balances compared with a "no-crisis-related-action scenario". Moreover, detailed information on the composition of fiscal packages is provided. It is evident from both data sources that the cross-country variation in the size of fiscal stimulus measures is substantial. According to (OECD 2010) the U.S. have passed the largest fiscal package in our sample of countries amounting to $5.6 \%$ of GDP in 2008 with tax and spending measures being comparable in size (3.2\% total tax measures vs. $2.4 \%$ spending measures) $)^{11}$.

Figures 7 and 8 (data from IMF 2012) present results for the relationship between the change in the general government structural balance from 2007 to 2008-11 and automatic stabilizers. These graphs indicate that countries with larger automatic stabilizers have passed smaller fiscal stimulus packages in the economic crisis.

As discretionary fiscal policy has varied enormously over the 2008-11 period, moving from highly expansionary to highly contractionary in some countries, we conduct the analysis separately for discretionary measures passed in 2008-09 (Figures 9a and 10a) and 2010-11 (Figures 9b and 10b).

While the negative correlation is visible for both sub-periods, it is much stronger (and hence also stronger than for the 2008-2011 average) for the first part of the crisis. Largest shifts from expansionary to contractionary fiscal policies can be observed for countries such as Greece or Ireland which received financial support from the European Financial Stability Facility (EFSF) under the condition of severe fiscal adjustment programs. In other countries fiscal policy was not expansionary (Austria, Germany, Italy) or contractionary (Hungary) even in the 2008-2009 period. Austerity measures recently implemented in many EU countries, in particular in Spain, Portugal or the UK, are only partly reflected in Figure 9b as they will persist to 2012 and beyond.

The negative correlation between automatic stabilizers and discretionary fiscal policy in 2008-2009 is confirmed when estimating multivariate regression equations controlling for 


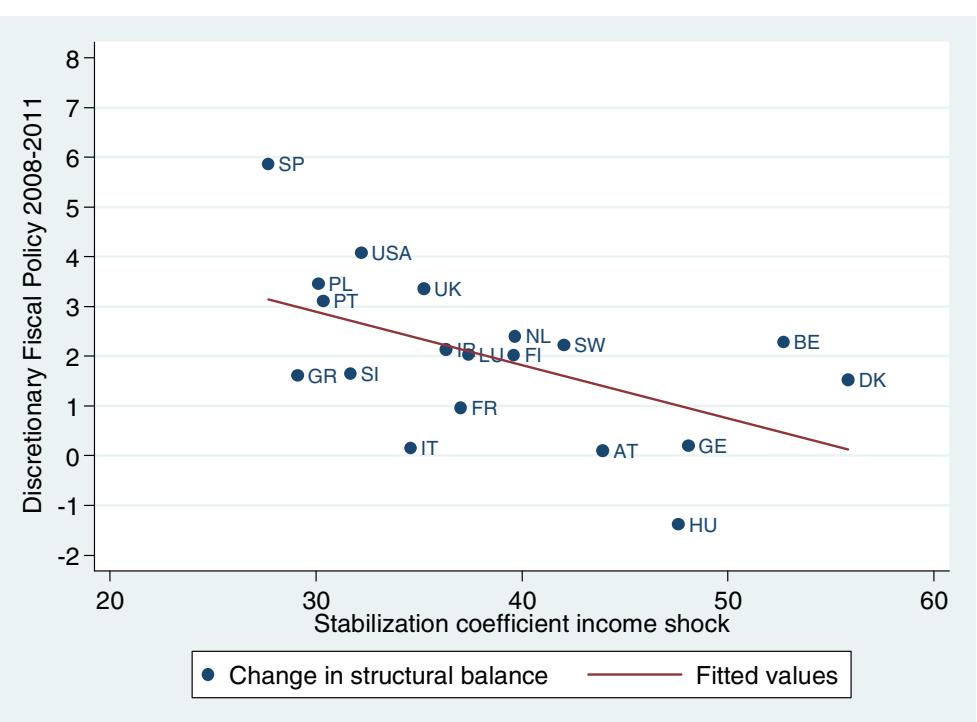

Figure 7 Change in structural balance (08-11) and automatic stabilizers. Source: Own calculations based on (EUROMOD and TAXSIM and IMF 2012).

various pre-determined variables. Controls include net interest payments, the debt/GDP ratio, two measures of fiscal space as suggested by (Aaizenman and Jinjarak 2010) ${ }^{12}$, the level of trade openness (defined as the ratio of imports and exports relative to GDP) and GDP per capita ${ }^{13}$. The first four regressors control for the budgetary situation in those countries under consideration before the start of the economic crisis ${ }^{14}$, trade openness and GDP per capita for other potentially important determinants of discretionary fiscal policy. All these controls are standard in this context (see, e.g. Bénétrix and Lane (2010)). All regressors are pre-determined since they are measured in the pre-crisis year 2007

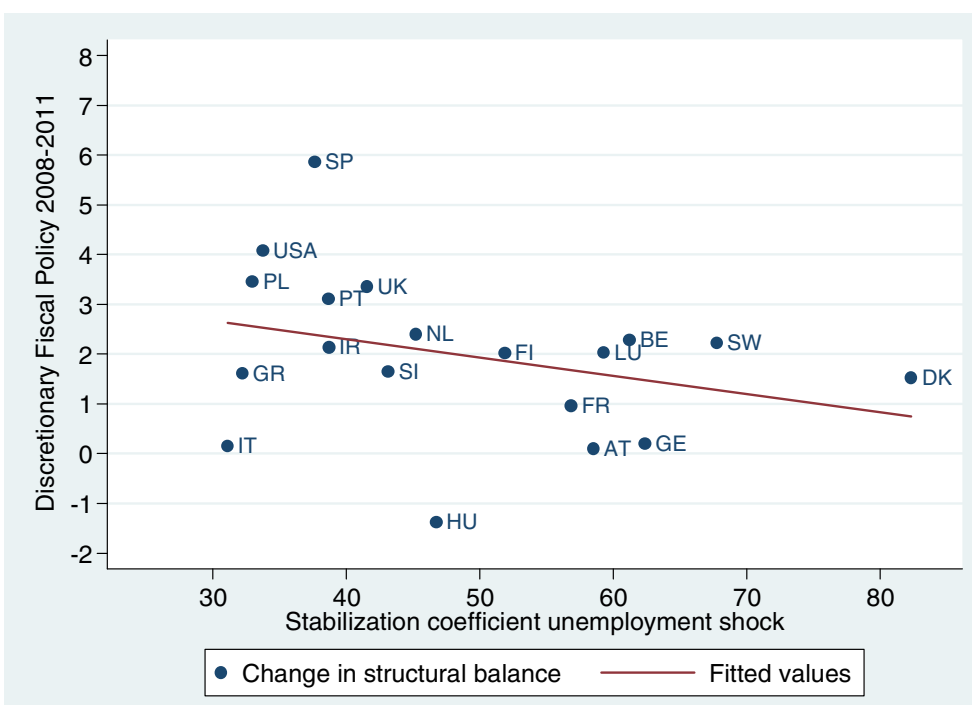

Figure 8 Change in structural balance and automatic stabilizers (unempl. shock). Source: Own calculations based on (EUROMOD and TAXSIM and IMF 2012). 
(a) 2008-09

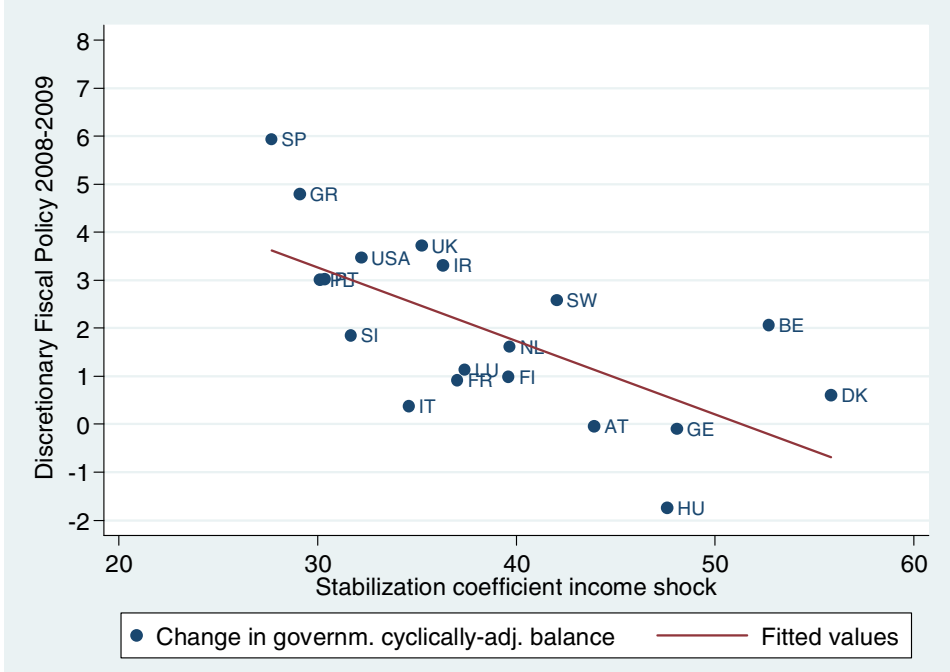

(b) $2010-11$

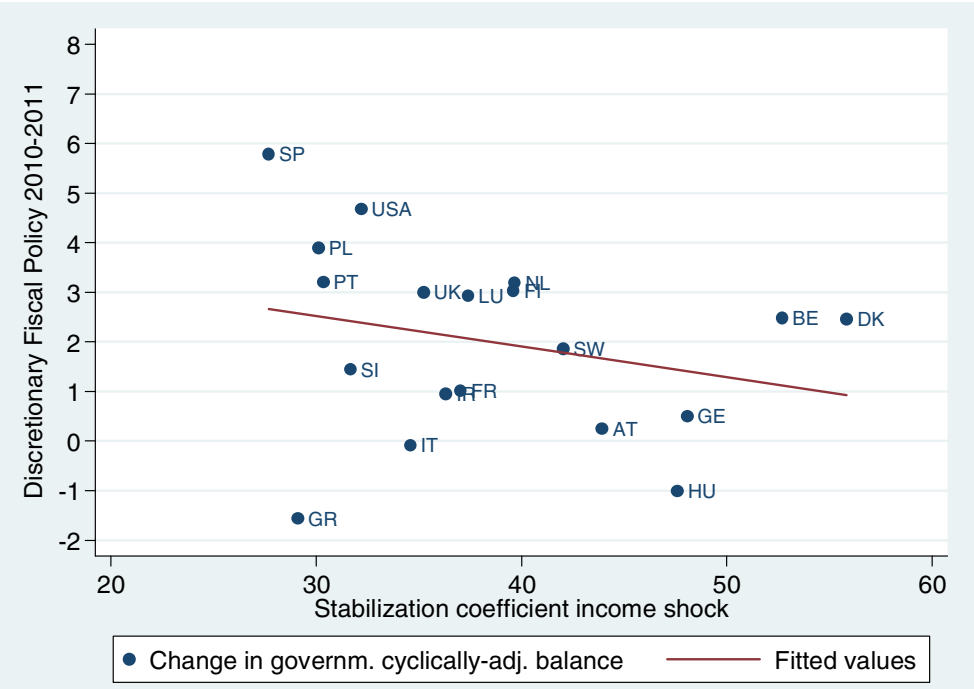

Figure 9 Change in structural balance and automatic stabilizer. Source: Own calculations based on (EUROMOD and TAXSIM and IMF 2012).

except the two measures of fiscal space which are based on averages for the years 20002006.

The results are shown in Table 1 . When interpreting them, it should be taken into account that they are based on 19 observations only. The coefficient for the size of automatic stabilizers (income stabilization coefficient) is significant in all specifications. The $\mathrm{R}^{2}$ indicates that the best fit is achieved with additional regressors controlling for the fiscal position before the start of the crisis. Our results thus confirm that countries whose fiscal position was weak before the economic crisis unfolded were constrained in their ability to react with discretionary fiscal stimulus (Romer 2012). 


\section{(a) $2008-09$}

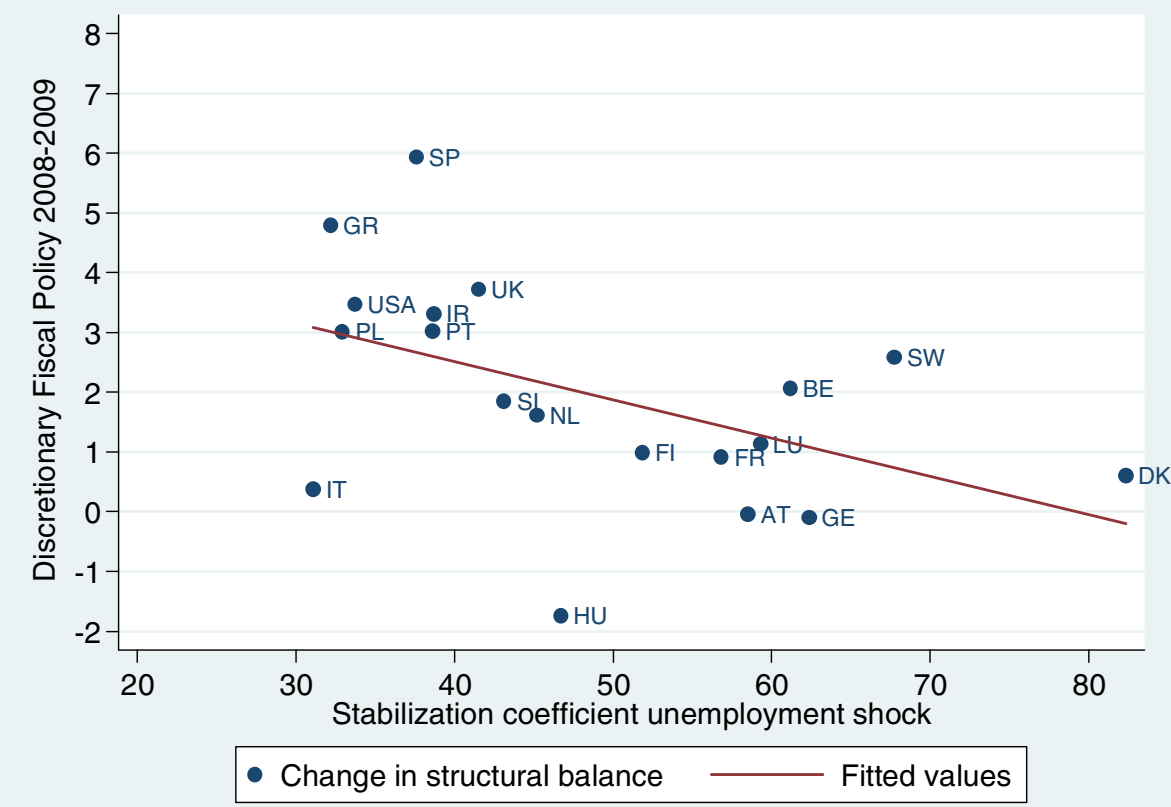

(b) $2010-11$

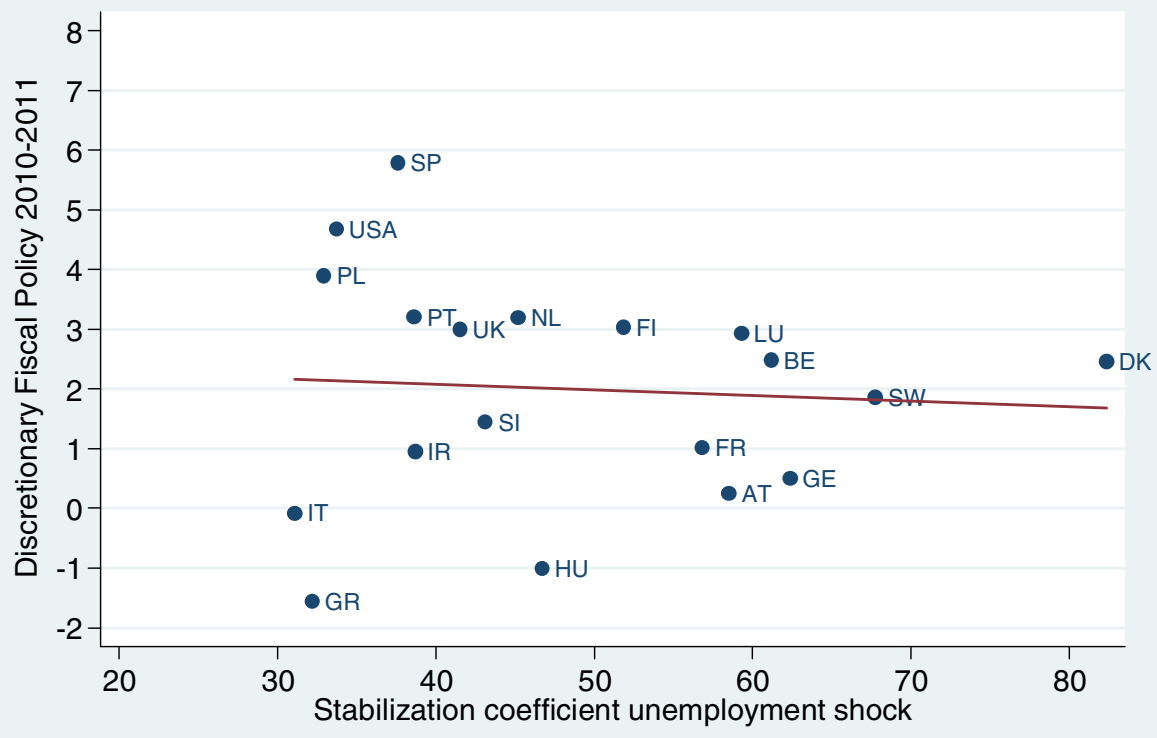

- Change in structural balance Fitted values

Figure 10 Change in structural balance and automatic stabilizers (unempl. shock). Source: Own calculations based on (EUROMOD and TAXSIM and IMF 2012).

Regression results with the income stabilization coefficient for the unemployment shock as dependent variable are presented in Table 2. The qualitative results are similar to those shown in Table 1 for the income shock. 
Table 1 Regression on change in structural balance - income stabilization income shock

\begin{tabular}{|c|c|c|c|c|c|c|c|}
\hline \multirow[b]{2}{*}{ Variables } & \multicolumn{7}{|c|}{ Dependent variable: Change in str. balance 2007 to $2008-09$} \\
\hline & (1) & $(2)$ & (3) & (4) & (5) & (6) & (7) \\
\hline \multirow{2}{*}{$\begin{array}{l}\text { Income stabilization coefficient } \\
\text { income shock }\end{array}$} & $-0.214^{* * *}$ & $-0.195^{* * *}$ & $-0.201^{* * *}$ & $-0.200^{* * *}$ & $-0.234^{* * *}$ & $-0.216^{* * *}$ & $-0.205^{* *}$ \\
\hline & $(0.042)$ & $(0.035)$ & $(0.035)$ & $(0.037)$ & $(0.041)$ & $(0.057)$ & $(0.042)$ \\
\hline \multirow[t]{2}{*}{ Net interest payments } & & $-0.738^{* * *}$ & & & & & \\
\hline & & $(0.234)$ & & & & & \\
\hline \multirow[t]{2}{*}{ Debt / GDP } & & & $-0.040^{* * *}$ & & & & \\
\hline & & & $(0.013)$ & & & & \\
\hline \multirow[t]{2}{*}{ Fiscal Space 1} & & & & $-0.945^{* *}$ & & & \\
\hline & & & & $(0.356)$ & & & \\
\hline \multirow[t]{2}{*}{ Fiscal Space 2} & & & & & $-8.666^{*}$ & & \\
\hline & & & & & $(4.605)$ & & \\
\hline \multirow[t]{2}{*}{ Openness } & & & & & & 0.001 & \\
\hline & & & & & & $(0.011)$ & \\
\hline \multirow[t]{2}{*}{ GDP per capita } & & & & & & & 0.012 \\
\hline & & & & & & & $(0.009)$ \\
\hline \multirow[t]{2}{*}{ Constant } & $10.148^{* * *}$ & $11.119^{* * *}$ & $12.166^{* * *}$ & $11.909^{* * *}$ & $11.613^{* * *}$ & $10.191^{* * *}$ & $8.279^{* * *}$ \\
\hline & $(1.527)$ & $(1.294)$ & $(1.407)$ & $(1.469)$ & $(1.623)$ & $(1.725)$ & (2.048) \\
\hline Observations & 19 & 18 & 19 & 19 & 19 & 19 & 19 \\
\hline$R^{2}$ & 0.600 & 0.761 & 0.749 & 0.723 & 0.673 & 0.600 & 0.640 \\
\hline
\end{tabular}

A further concern in the policy debate put forward by supporters of large and coordinated discretionary measures was that countries could limit the size of their programs at the expense of countries with more generous fiscal policy responses. The central factor behind this hypothesis is the degree of openness of an economy. The more open an economy is, i.e. the stronger the economic ties with other countries are, the more likely it is that a country gains from other countries' fiscal stimulus packages or, conversely, the more likely it is that own fiscal stimulus measures spill over to other countries. Hence, the idea behind this argument is that some countries might show a free-rider behavior and profit from spill-over effects of discretionary measures ${ }^{15}$. We find only weak evidence for this hypothesis. While the correlation between discretionary measures passed in 2008-2009 and trade openness is negative which is confirmed when we estimate a univariate regression between these two ${ }^{16}$, the coefficient on openness becomes insignificant once our measure for automatic stabilization is included as can be seen in column (6) of Table 1. This is due to the fact that the correlation between openness and automatic stabilization is positive. All in all, our results suggest that policymakers did take into account the forces of automatic stabilizers when designing active fiscal policy measures to tackle the recent economic crisis.

\section{Conclusions and policy implications}

Fiscal policy has been a central tool for governments to counteract economic stagnation in the recent crisis, both in terms of automatic stabilization as well as discretionary fiscal policy. Many papers have investigated the effectiveness of stabilization policies in 
Table 2 Regression on change in structural balance - income stabilization unempl shock

\begin{tabular}{|c|c|c|c|c|c|c|c|}
\hline \multirow[b]{2}{*}{ Variables } & \multicolumn{7}{|c|}{ Dependent variable: Change in str. balance 2007 to $2008-09$} \\
\hline & (1) & $(2)$ & (3) & (4) & $(5)$ & (6) & (7) \\
\hline \multirow{2}{*}{$\begin{array}{l}\text { Income stabilization coefficient } \\
\text { unempl. shock }\end{array}$} & $-0.089^{* * *}$ & $-0.096^{* * *}$ & $-0.103^{* * *}$ & $-0.096^{* * *}$ & $-0.106^{* * *}$ & $-0.071^{*}$ & $-0.083^{* *}$ \\
\hline & $(0.028)$ & $(0.021)$ & $(0.020)$ & $(0.023)$ & $(0.029)$ & $(0.035)$ & $(0.029)$ \\
\hline \multirow[t]{2}{*}{ Net interest payments } & & $-1.057^{* * *}$ & & & & & \\
\hline & & $(0.259)$ & & & & & \\
\hline \multirow[t]{2}{*}{ Debt / GDP } & & & $-0.060^{* * *}$ & & & & \\
\hline & & & $(0.014)$ & & & & \\
\hline \multirow[t]{2}{*}{ Fiscal Space 1} & & & & $-1.371^{* * *}$ & & & \\
\hline & & & & $(0.408)$ & & & \\
\hline \multirow[t]{2}{*}{ Fiscal Space 2} & & & & & -9.687 & & \\
\hline & & & & & (6.149) & & \\
\hline \multirow[t]{2}{*}{ Openness } & & & & & & -0.011 & \\
\hline & & & & & & $(0.012)$ & \\
\hline \multirow[t]{2}{*}{ GDP per capita } & & & & & & & 0.012 \\
\hline & & & & & & & $(0.012)$ \\
\hline \multirow[t]{2}{*}{ Constant } & $6.268^{* * *}$ & $8.893^{* * *}$ & $10.529^{* * *}$ & $9.824^{* * *}$ & $7.783^{* * *}$ & $6.147^{* * *}$ & $4.556^{*}$ \\
\hline & $(1.228)$ & $(1.107)$ & (1.336) & $(1.434)$ & $(1.520)$ & $(1.239)$ & $(2.195)$ \\
\hline Observations & 19 & 18 & 19 & 19 & 19 & 19 & 19 \\
\hline$R^{2}$ & 0.368 & 0.700 & 0.700 & 0.630 & 0.453 & 0.401 & 0.401 \\
\hline
\end{tabular}

the recent recession, but little is known on the relationship between the two components of fiscal policy. The aim of this paper is to fill this gap.

Using up-to-date data on discretionary fiscal policy and two measures of automatic stabilization - income stabilization coefficients resulting from an income and an unemployment shock scenario - we find that countries with larger automatic stabilizers tended to enact smaller fiscal stimulus packages in the recent economic crisis. The US, for example, a country with rather small automatic stabilizers - both in an international perspective as well as in its own historical context - was the country with the largest fiscal stimulus package amounting to $5.6 \%$ of GDP. Given the low automatic stabilizers, however, the total effect of fiscal policy in the US has been more moderate than the size of the discretionary program might suggest. Of course, there are other determinants of discretionary fiscal policy. We find that the fiscal position of each country before the start of the crisis was a further important determinant for the size of discretionary fiscal stimulus packages.

Our results suggest that social protection systems, and in particular out-of-work benefits, play a key role for the stabilization of disposable incomes and explain a large part of the difference in automatic stabilizers between Europe and the US. This is confirmed by the decomposition of stabilization effects in our analysis. In the case of the unemployment shocks, benefits alone absorb 19\% of the shock in Europe compared to just 7\% in the US, whereas the stabilizing effect of income taxes (taking into account state taxes in the US as well) is similar. Note, however, that considerable heterogeneity exists within Europe.

Automatic stabilizers have the major advantage of providing income replacement immediately, i.e. when unemployment starts to rise and incomes fall. While means- 
tested income support is generally available as a basic social security net in most EU Member States, unemployment insurance systems are more exclusive as they do not protect all types of workers equally. As the extent of unemployment risks and the 'quality' of social protection provided to different socio-economic groups does not coincide, one can argue that in general those most affected are the least protected. Here, a discretionary expansion of benefit generosity or easing access to benefits can play a substantial role in reaction to crises. However, discretionary changes to benefit systems or the creation of new benefits may take some time and may be more difficult to administer and deliver, in particular if new groups are to be integrated or new benefits created - or if fiscal restrictions are considered. Therefore, it might be worth to redesign active and passive labor market policies in such a way that they automatically respond to cyclical variations as for instance the extended unemployment insurance in Canada and the US. How to optimally design such instruments in an automatic way provides an interesting avenue for future research.

A limitation of our analysis is that we only consider a rather small sample of European countries as well as the US. It would be interesting to extend this analysis also to developing countries.

\section{Endnotes}

${ }^{1}$ Previous research on automatic stabilization has mainly relied on macro data (e.g. Girouard and André (2005)). Exceptions based on micro data are (Auerbach and Feenberg 2000) and (Knieser and Ziliak 2002a, b) for the US and (Mabbett and Schelkle 2007) for the EU-15. As it is common in this literature, we have to assume the full takeup of social benefits for our simulations which might overestimate the automatic stabilizer measures in countries where non-take-up is important. In addition, we abstract from any (potential) behavioral responses as we are interested in separating the automatic response from discretionary and general equilibrium effects.

${ }^{2}$ See (Galí 1994), (Fatás and Mihov 2001) or (Debrun et al. 2008) for the positive association between government size and automatic stabilizers and their dampening effect on GDP volatility.

${ }^{3}$ We abstract from other taxes, in particular corporate income taxes. For an analysis of automatic stabilizers in the corporate tax system, see (Devereux and Fuest 2009) and (Buettner and Fuest 2010).

${ }^{4}$ For more information on TAXSIM see (Feenberg and Coutts 1993) or visit http:// www.nber.org/taxsim/. For further information on EUROMOD see (Sutherland 2001, 2007). There are also country reports available with detailed information on the input data, the modeling and validation of each tax benefit system and the underlying data, see http://www.iser.essex.ac.uk/research/euromod. The tax-benefit systems included in the model have been validated against aggregated administrative statistics in order to make sure they reflect the initial baseline conditions in each country as well as national tax-benefit models (where available), and the robustness checked through numerous applications (see e.g. Bargain (2006)).

${ }^{5}$ Our scenarios can be seen as a conservative estimate of the expected impact of the recent crisis (see Reinhart and Rogoff (2009)) for effects of previous crises). The 
(qualitative) results are robust with respect to different sizes of the shocks. The results for the unemployment shock do not change much when we model it as an increase of the unemployment rate by 5 percentage points for each country. It would be further possible to derive more complicated scenarios with different shocks on different income sources or a combination of income and unemployment shock. However, this would only have an impact on the distribution of changes which are not relevant in the analysis of this paper. Therefore, we focus on these two simple scenarios in order to make our analysis as simple as possible. One should note, though, that our analysis is not a forecasting exercise. We do not aim at quantifying the exact effects of the recent economic crisis but of stylized scenarios in order to explore the build-in automatic stabilizers of existing pre-crisis tax-benefit systems. Conducting an ex-post analysis would include discretionary government reactions and behavioral responses (see, e.g., Aaberge et al. (2000) for an empirical ex-post analysis of a previous crisis in the Nordic countries) and we would not be able to identify the role of automatic stabilization.

${ }^{6}$ For the reweighting procedure, we follow the approach of Immvervoll et al. (2006), who have also simulated an increase in unemployment through reweighting of the sample. Their analysis focuses on changes in absolute and relative poverty rates after changes in the income distribution and the employment rate. The reweighting approach is the only feasible option for this scenario as EUROMOD does not simulate unemployment benefits for all countries (but takes it from the data).

${ }^{7}$ Cf. Deville and Särndal (1992) and DiNardo et al. (1996). This approach is equivalent to estimating probabilities of becoming unemployed (Bell and Blanchflower 2009) and then selecting the individuals with the highest probabilities when controlling for the same characteristics in the reweighting estimation (see Herault (2009)). One should note, however, that this leads to a downward bias of the short-run stabilization as unemployment benefits depend strongly on unemployment duration and would be higher for newly unemployed compared to long-term unemployed.

${ }^{8}$ Note that for the US the value of the stabilization coefficient for the federal income tax only is below 25\% which is in line with the results of (Auerbach and Feenberg 2000).

${ }^{9}$ Note that we do not account for the Extended Benefits (EB) program in the US because it does not kick in automatically in all states. The EB program provides an additional 13 to 20 weeks of unemployment benefits to workers receiving unemployment insurance in states that meet certain thresholds in terms of their unemployment rates. This increased duration of unemployment benefits slightly increases the stabilization coefficient for the US and, thus, reduces the difference to the EU.

${ }^{10}$ For more detailed descriptions of the structural balance, see (Girouard and André 2005) for the OECD- and (Fedelino et al. 2009) for the IMF-methodology. A discussion of this concept can be found in (Blanchard 1993) and (Mohr and Morris 2007). In short, there are several conceptual difficulties in separating the cyclical component of fiscal policy from structural movements which requires strong assumptions on potential output and cyclical elasticities of different fiscal variables. These methodological problems can lead to sizeable ex-post revisions of structural balances. Note that the results presented in this section do not change if we base our analysis on (IMF 2011). 
${ }^{11}$ Note that a portion of the U.S. stimulus package was devoted to its states which all have some form of balanced budget rules. Hence, the purpose of this policy was to avoid weakening automatic stabilizers at this lower level of government.

${ }^{12}$ Aaizenman and Jinjarak (2010) define the first measure (fiscal space 1) as the size of public debt relative to tax revenue and the second one (fiscal space 2) as the size of government deficit relative to tax revenue.

${ }^{13}$ Information on net interest payments, debt/GDP ratio and GDP per capita is from (IMF 2012) and the level of trade openness is taken from (Heston et al. 2006).

${ }^{14}$ The negative effects of a fiscal expansion for countries with unsustainable fiscal positions have already been emphasized at an early stage in the recession, see Spilimbergo et al. (2008).

${ }^{15}$ In that sense, a fiscal stimulus program can be seen as a positive externality since potential positive effects are not limited to the country of origin.

${ }^{16}$ The univariate regression is not shown separately, but available from the authors upon request.

\section{Competing interests}

The IZA Journal of Labor Policy is committed to the IZA Guiding Principles of Research Integrity. The authors declare that they have observed these principles.

\section{Acknowledgements}

This paper uses EUROMOD D21 and TAXSIM v9. EUROMOD and TAXSIM are continually being improved and updated and the results presented here represent the best available at the time of writing. Our version of TAXSIM is based on the Survey of Consumer Finances (SCF) by the Federal Reserve Board. EUROMOD relies on micro-data from 17 different sources for 19 countries. These are ECHP and EU-SILC (Eurostat), Austrian version of ECHP (Statistik Austria); PSBH (University of Liège and University of Antwerp); Estonian HBS (Statistics Estonia); Income Distribution Survey (Statistics Finland); EBF (INSEE); GSOEP (DIW Berlin); Greek HBS (National Statistical Service of Greece); Living in Ireland Survey (ESRI); SHIW (Bank of Italy); PSELL-2 (CEPS/INSTEAD); SEP (Statistics Netherlands); Polish HBS (Warsaw University); Slovenian HBS and Personal Income Tax database (Statistical Office of Slovenia); Income Distribution Survey (Statistics Sweden); and the FES (UK ONS through the Data Archive). Material from the FES is Crown Copyright and is used by permission. Neither the ONS nor the Data Archive bears any responsibility for the analysis or interpretation of the data reported here. An equivalent disclaimer applies for all other data sources and their respective providers. This paper is partly based on work carried out during Peichl's visit to ECASS at ISER, University of Essex, supported by the EU Improving Human Potential Programme. Peichl is grateful for financial support by Deutsche Forschungsgemeinschaft DFG (PE1675). Fuest acknowledges financial support from the ESRC (Grant No RES-060-25-0033). We are grateful to Daniel Feenberg for granting us access to NBER's TAXSIM and helping us with our simulations. We are indebted to all past and current members of the EUROMOD consortium for the construction and development of EUROMOD. The usual disclaimer applies.

\section{Author details}

${ }^{1}$ IZA, Schaumburg-Lippe-Str. 5-9, 53113, Bonn, Germany. ${ }^{2}$ Saïd Business School, University of Oxford, Park End Street, Oxford OX1 1HP, UK.

Received: 19 July 2012 Accepted: 14 September 2012

Published: 6 November 2012

\section{References}

Aaizenman J, Jinjarak Y (2010) De facto fiscal space and fiscal stimulus: Definition and assessment, NBER Working Paper No. 16539. National Bureau of Economic Research, Cambridge, MA

Aaberge R, Björklund A, Jäntti M, Pedersen PJ, Smith N, Wennemo T (2000) Unemployment Shocks and Income Distribution: How Did the Nordic Countries Fare during Their Crises? Scandinavian Journal of Economics 102(1):77-99

Alesina A, Glaeser E (2004) Fighting Poverty in the U.S. and Europe: A World of Difference. Oxford University Press, New York Auerbach A (2009) Implementing the New Fiscal Policy Activism. American Economic Review 99(2):543.49

Auerbach A, Feenberg D (2000) The significance of federal taxes as automatic stabilizers. Journal of Economic Perspectives 14:37-56

Bargain O (2006) Microsimulation in action: policy analysis in Europe using EUROMOD vol. 25 of the series Research in Labor Economics. Elsevier

Bell DNF, Blanchflower DG (2009) "What should be done about rising unemployment in the UK?", IZA Discussion Papers, No. 4040. IZA, Bonn

Bénétrix A, Lane P (2010) International differences in fiscal policy during the global crisis, NBER Working Paper No. 16346. National Bureau of Economic Research, Cambridge, MA

Blanchard O (1993) Suggestions for a new set of fiscal indicators. In: Verbon HAA, van Winden FAAM (eds) The New Political Economy of Government Debt. Elsevier Science Publishers, North-Holland, Amsterdam 
Bourguignon F, Spadaro A (2006) Microsimulation as a tool for evaluating redistribution policies. Journal of Economic Inequality 4(1):77-106

Buettner T, Fuest C (2010) The Role of the Corporate Income Tax as an Automatic Stabilizer. International Tax and Public Finance 17(6):686-698

Debrun X, Pisany-Ferry J, Sapir A (2008) Government Size and Output Volatility: Should we Forsake Automatic Stabilization? Economic Papers 316. European Economy, Brussels

Devereux M, Fuest C (2009) Is the Corporation Tax an Effective Automatic Stabilizer? National Tax Journal LXI:429-437

Deville J-F, Särndal C-E (1992) Calibration estimators in survey sampling. Journal of the American Statistical Association 87:376-382

DiNardo J, Fortin N, Lemieux T (1996) Labor Market Institutions and the Distribution of Wages, 1973-1992: A Semiparametric Approach. Econometrica 64:1001-1044

Dolls M, Fuest C, Peichl A (2012) Automatic Stabilizers and Economic Crisis: US vs. Europe. Journal of Public Economics 96:279-294

Fatás A, Mihov I (2001) "Government size and automatic stabilisers: International and intranational evidence". Journal of International Economics 55(1):3-28

Fatás A, Mihov I (2009) The Euro and Fiscal Policy, NBER Working Paper No. 14722. National Bureau of Economic Research, Cambridge, MA

Fedelino A, Ivanova A, Horton M (2009) Computing Cyclically Adjusted Balances and Automatic Stabilizers. IMF Technical Notes and Manuals, Washington, D.C.

Feenberg DR, Coutts E (1993) An Introduction to the TAXSIM Model. Journal of Policy Analysis and Management 12 (1):189-194

Galí J (1994) Government size and macroeconomic stability. European Economic Review 38:117-132

Girouard N, André C (2005) Measuring cyclically-adjusted budget balances for OECD countries. OECD Economics Department Working Papers No. 434, OECD, Paris

Herault N (2009) Sequential Linking of Computable General Equilibrium and Microsimulation Models. International Journal of Microsimulation 3(1):35-42

Heston A, Summers R, Aten B (2006) Penn World Table Version 6.2. Center for International Comparisons of Production, Income and Prices at the University of Pennsylvania, Philadelphia, Pennsylvania

IMF (2009) Group of Twenty - Global Economic Policies and Prospects. Note by the Staff of the International Monetary Fund, IMF, Washington, D.C.

IMF (2011) World Economic Outlook - Slowing Growth, Rising Risks. IMF, Washington, D.C.

IMF (2012) World Economic Outlook - Growth Resuming, Dangers Remain. IMF, Washington, D.C.

Immvervoll H (2004) Average and marginal effective tax rates facing workers in the EU. A micro-level analysis of levels, distributions and driving factors, EUROMOD Working Paper Series.

Immvervoll H, Levy H, Lietz C, Mantovani D, Sutherland H (2006) The sensitivity of poverty rates to macro-level changes in the European Union. Cambridge Journal of Economics 30:181-199

Knieser T, Ziliak J (2002) Tax Reform and Automatic Stabilization. American Economic Review 92(3):560-612

Mabbett D, Schelkle W (2007) Bringing macroeconomics back into the political economy of reform: the Lisbon Agenda and the 'fiscal philosophy' of the EU. Journal of Common Market Studies 45:81-104

Mohr M, Morris R (2007) Uncertainty in Measuring the underlying budgetary position and fiscal stance, Paper presented at the Directorate General for Economic and financial Affairs 2008 workshop "Achieving \& safeguarding sound fiscal positions". European Commission, Brussels

OECD (2009) The Effectiveness and Scope of Fiscal Stimulus. In: OECD Economic Outlook interim report. OECD Publishing, Paris

OECD (2010) OECD Factbook 2010: Economic, Environmental and Social Statistics; Special Focus: The crisis and beyond. OECD Publishing, Paris, http://dx.doi.org/10.1787/factbook-2010-en

OECD (2012) OECD Employment Outlook 2012. OECD Publishing, Paris, http://dx.doi.org/10.1787/empl_outlook-2012-en

Pechman J (1973) Responsiveness of the Federal Income Tax to Changes in Income. Brookings Papers on Economic Activitiy 2:385-421

Pechman J (1987) Federal Tax Policy. Brookings, Washington

Piketty T, Saez E (2007) How Progressive is the U.S. Federal Tax System? A Historical and International Perspective. Journal of Economic Perspectives 21(1):3-24

Reinhart C, Rogoff K (2009) The Aftermath of Financial Crisis. American Economic Review: Papers \& Proceedings 99 (2):466-472

Romer C (2012) Fiscal Policy in the Crisis: Lessons and Policy Implications, IMF Fiscal Forum

Spilimbergo A, Symansky S, Blanchard O, Cottarelli C (2008) Fiscal Policy for the Crisis, IMF Staff Position Note. IMF, Washington, D.C.

Sutherland H (2001) Final Report - EUROMOD: An Integrated European Benefit-Tax Model, EUROMOD Working Paper No. EM9/01. University of Cambridge, Department of Applied Economics, Cambridge, UK

Sutherland H (2007) Euromod: the tax-benefit microsimulation model for the European Union. In: Gupta A, Harding A (eds) Modelling Our Future: Population Ageing, Health and Aged Care, Vol. 16 of International Symposia in Economic Theory and Econometrics. Elsevier, North-Holland, Amsterdam, pp 483-488

van den Noord P (2000) "The size and role of automatic fiscal stabilisers in the 1990s and beyond", OECD Economics Department Working Papers, No. 230. OECD, Paris

doi:10.1186/2193-9004-1-4

Cite this article as: Dolls et al: Automatic stabilization and discretionary fiscal policy in the financial crisis. IZA Journal of Labor Policy 2012 1:4. 